\title{
Sense of coherence and burnout in the energy and chemicals industry: The moderating role of age
}

\begin{tabular}{|c|c|}
\hline \multicolumn{2}{|c|}{$\begin{array}{l}\text { Authors: } \\
\text { Sanet van der Westhuizen }{ }^{1} \\
\text { Charmaine Horn }^{2} \\
\text { Alana Viljoen }\end{array}$} \\
\hline \multicolumn{2}{|c|}{$\begin{array}{l}\text { Affiliations: } \\
{ }^{1} \text { Department of Industrial } \\
\text { and Organisational } \\
\text { Psychology, University of } \\
\text { South Africa, South Africa }\end{array}$} \\
\hline \multicolumn{2}{|c|}{$\begin{array}{l}{ }^{2} \text { SGS SHE PSS Behaviour } \\
\text { Transformation, SASOL } \\
\text { Mining, South Africa }\end{array}$} \\
\hline \multicolumn{2}{|c|}{$\begin{array}{l}{ }^{3} \text { Employee Relations, SGS } \\
\text { SASOL Mining, South Africa }\end{array}$} \\
\hline \multicolumn{2}{|c|}{$\begin{array}{l}\text { Correspondence to: } \\
\text { Sanet van der Westhuizen }\end{array}$} \\
\hline \multicolumn{2}{|c|}{$\begin{array}{l}\text { Email: } \\
\text { vdwessc@unisa.ac.za }\end{array}$} \\
\hline \multicolumn{2}{|c|}{$\begin{array}{l}\text { Postal address: } \\
\text { PO Box 392, Universi } \\
\text { South Africa 0003, } \\
\text { South Africa }\end{array}$} \\
\hline \multicolumn{2}{|c|}{$\begin{array}{l}\text { Dates: } \\
\text { Received: } 14 \text { Apr. } 2015 \\
\text { Accepted: } 18 \text { Sept. } 2015 \\
\text { Published: } 30 \text { Nov. } 2015\end{array}$} \\
\hline \multicolumn{2}{|c|}{$\begin{array}{l}\text { How to cite this article: } \\
\text { Van der Westhuizen, S., } \\
\text { Horn, C., \& Viljoen, A. (2015). } \\
\text { Sense of coherence and } \\
\text { burnout in the energy and } \\
\text { chemicals industry: The } \\
\text { moderating role of age. SA } \\
\text { Journal of Human Resource } \\
\text { Management/SA Tydskrif vir } \\
\text { Menslikehulpbronbestuur, } \\
\text { 13(1), Art. \#705, } 9 \text { pages. } \\
\text { http://dx.doi.org/10.4102/ } \\
\text { sajhrm.v13i1.705 }\end{array}$} \\
\hline \multicolumn{2}{|c|}{$\begin{array}{l}\text { Copyright: } \\
\text { (C) 2015. The Authors. } \\
\text { Licensee: AOSIS } \\
\text { OpenJournals. This wor } \\
\text { licensed under the Crea } \\
\text { Commons Attribution } \\
\text { License. }\end{array}$} \\
\hline \multicolumn{2}{|l|}{ Read online: } \\
\hline 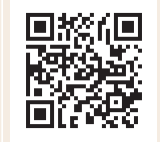 & $\begin{array}{l}\text { Scan this QR } \\
\text { code with your } \\
\text { smart phone or } \\
\text { mobile device } \\
\text { to read online. }\end{array}$ \\
\hline
\end{tabular}

Orientation: Organisations are accommodating four different social generations in the working environment. This poses a challenge for Human Resources departments to manage these diverse age cohorts in the workforce, as they are likely to have different needs, values and variables affecting their wellness.

Research purpose: The objective of the present study was to assess whether various age groups differ with regard to their sense of coherence and burnout, and whether age significantly moderates the relationship between sense of coherence and burnout.

Motivation for the study: Although the literature review suggests that age groups may differ with regard to their sense of coherence and burnout, the findings seem to be somewhat inconclusive in this regard. There also seems to be a paucity of research examining the interaction effect between sense of coherence, burnout and age.

Research approach, design and method: A cross-sectional quantitative survey approach was used. A nonprobability convenience sample of adults $(N=246)$ - employed in South Africa by an international integrated energy and chemicals company - participated in the study. Correlation, analysis of variance (ANOVA) and hierarchical multiple regression analyses were performed to achieve the objectives of the study.

Main findings: The results showed that employees between the ages of 51 and 60 years of age experienced higher levels of comprehensibility and lower levels of reduced professional efficacy than their younger counterparts. The relationship between sense of coherence and exhaustion was also stronger for employees between 51 and 60 years old than for younger age categories.

Practical/managerial implications: The results of the study can be useful when planning human resource interventions to enhance the well-being of employees from different age groups.

Contribution: The results of the study add new insights to the well-being literature by showing that employees' age is important to consider when addressing their sense of coherence and burnout levels.

\section{Introduction}

Life expectancy and the average age of the population are increasing (Johnson, Holdsworth, Hoel \& Zapf, 2013). This demographic change has an impact on the age structures of the working population (Boehm \& Kunze, 2015). It seems that organisations need to accommodate four different social generations (the silent generation, baby boomers, generation $X$ and generation $Y$ or millennials) in the working environment (Culpin, Millar \& Peters, 2015). It leaves management with unprecedented challenges associated with the diverse age cohorts in the workforce. Starting out in a career may involve stressful experiences that include integrating into the social context at work and still being uncertain about one's knowledge and skills (Virtanen \& Koivisto, 2001). Younger employees who start out eagerly in the organisation may become disheartened (e.g. exerting themselves to perform or experiencing transitional shock when starting out) and as a result spiral into burnout (Rothmann \& Malan, 2006). Midcareer workers may report work-family conflict as one of their main stressors (Culpin et al., 2015). Mature workers still want to make a contribution to the organisation and society (Dychtwald, Erickson \& Morison, 2013), but may have different health needs. It seems that each of these generations or different age categories has their own set of needs, expectations, values, skills and attitudes that needs to be taken into account when ensuring a productive workforce (Culpin et al., 2015).

Mauno, Ruokalainen and Kinnunen (2013) investigated the moderating effect of age between various job stressors and well-being indicators. They found that younger employees seemed to 
be better equipped to handle job insecurity in comparison to their older counterparts. Older employees were better able to cope with work-family imbalance and high workload. Haley, Mostert and Els (2013) also found that different job demands and resources seem to predict burnout and work engagement of various age groups. Thus, it seems that in addressing the well-being of employees, a greater understanding of age differences might be needed, whilst different stress management interventions might be needed for older and younger employees. In light of this, the aim of this study is therefore to look at the relationship between age, sense of coherence and burnout of employees, and to determine if age moderates the relationship between sense of coherence and burnout.

\section{Literature review}

\section{Age}

Studying the effects of age in the workplace is not a new phenomenon. Ageism and the influence of generations at work are well-researched domains (Hansen \& Leuty, 2012; Iweins, Desmette, Yzerbyt \& Stinglhamber, 2013). But it seems that organisations will soon have to adapt to an even more age diverse workforce. This seems eminent as a result of a number of trends worldwide like low birth rates, increased longevity and the war for talent which forces organisations to hire older workers (Boehm \& Khunze, 2015). One of the consequences of these trends is that the number of older workers is likely to increase in the future (Zaniboni, Truxillo \& Fraccaroli, 2013). Organisations are faced with the task to create environments that attract and satisfy workers of all ages (Hansen \& Leuty, 2012). Since some disagreement exist regarding what birth years define the various generations, this study will look at differences between age groups and not generational differences per se. This approach is also in line with other researchers that have looked at the influence of age on sense of coherence and burnout (Feldt et al., 2011; Haley et al., 2013; Maslach, Schaufeli \& Leiter, 2001).

\section{Sense of coherence and age}

Antonovsky (1987) initially coined the term salutogenesis and developed the key construct of sense of coherence (SOC) as conceptual anchor to the salutogenic theory. Since then, a steady stream of research has been generated to understand wellbeing and adjustment, also specifically in the workplace (Barnard, 2013). These studies have shown how SOC affects employees' coping with work-life demands and enhance their performance and goal-achieving ability (Barnard, 2013).

Antonovsky (1987) defined SOC as a dispositional life orientation that includes three subcomponents, namely comprehensibility, that enables an individual to see the environment as structured and ordered; manageability, through which individuals perceive that they have adequate resources to manage life demands; and meaningfulness, by which individuals believe that life demands are worth spending energy and effort on.
Antonovsky (1987) originally believed that SOC develops through early adulthood and then stabilises after the age of 30 (this is called the 'age hypothesis'). This development then also takes place during the first years of employment in which young adults establish a sense of identify and form a world view.

Subsequent international studies on SOC stability over 30 years reveal mixed results, with some concurring the 'age hypothesis' (Feldt et al., 2011; Hochwälder \& Forsell, 2011), whilst others could not confirm the stability of SOC after the age of 30 years (Eriksson \& Lindström, 2005; Wainwright et al., 2008). A South African study by Van Schalkwyk and Rothmann (2008) could also not confirm that SOC stabilises after 30 years of age. Instead, they found that SOC steadily increased with 10-year intervals and then levelled off beyond 50 years of age. These findings seem to be in line with the idea that SOC can be associated with 'the progressive and time-related mastering of work and life complexities' (Van Schalkwyk \& Rothmann, 2008, p. 37).

Looking purely at the differences between age groups, Feldt et al. (2011) found that older adults displayed significantly higher SOC levels in comparison with their younger counterparts. The mean level of SOC did however increase more for the younger adults (Barnard, 2013). More recently, Mattisson, Horstmann and Bogren (2014) also found that SOC increases with age. A South African study by Haley et al. (2013) also found that older employees experienced higher levels of SOC. These results guided the researchers to the first research hypothesis to be tested:

- Hypothesis 1: SOC levels are higher for older age categories (51-60-year-old age group).

\section{Burnout and age}

The incidence of burnout had increased over the past 30 years with dire consequences for organisations' performance and employees' health (Abdool Karrim Ismail, Coetzee, Du Toit, Rudolph \& Joubert, 2013). Schaufeli and Enzmann (1998) defined burnout as:

a persistent, negative work-related state of mind in normal individuals that is primarily characterised by exhaustion, which is accompanied by distress, a sense of reduced effectiveness, decreased motivation and the development of dysfunctional attitudes and behaviours at work. (p. 36)

More recently, burnout was described as a multidimensional construct that is evident in employees' 'experiences of physical and psychological exhaustion, depersonalisation, frustration and reduced sense of personal accomplishment ${ }^{\prime}$ (Abdool Karrim Ismail et al., 2013, p. 452). Burnout is believed to develop as a result of prolonged exposure to stressors or an imbalance between demands and resources to employees' disposal at work (Storm \& Rothmann, 2003).

South African research conducted by Smit (2007) indicated age to be the most consistent demographic variable to be linked with burnout. The theory of burnout seems to suggest 
that burnout is consistently higher in younger employees than in older employees (Maslach et al., 2001). Due to the relationship between age and work experience, burnout seems to be more of a threat early in an individual's career (Asiwe, Jorgensen \& Hill, 2014). Young employees who are new to the profession may be idealistic and eager to perform and progress professionally (Louw, George \& Esterhuyse, 2011) and, as a result, may exert themselves or experience some transitional shock when just entering the workplace. As a result of less experience in a working environment, younger employees may also lack the coping skills necessary to deal with everyday stressors (Haley et al., 2013).

Nevertheless, research findings with regard to the relationship between age and burnout have not been consistent. Brewer and Shapard (2004) found a negative relationship between age and burnout in a meta-analytical study. These findings were confirmed by Johnson et al. (2013) who found a negative relationship between age on the one hand and emotional exhaustion and cynicism on the other. No relationship was evident between age and reduced professional efficacy. BenPorat and Itzhaky (2014) also found older employees to have lower levels of burnout.

South African studies are also in alignment with these international findings and indicated burnout to be more prominent for younger employees (Haley et al., 2013; Jackson \& Rothmann, 2005; Rothmann \& Barkhuizen, 2008) However, Bezuidenhout and Cilliers (2011) did not find any relationship between age and burnout levels of female academics, whilst Asiwe et al. (2014) found that younger employees had lower fatigue levels than older employees. Mousavy and Nimehchisalem (2014) also found that older teachers were more burned out than their younger counterparts.

The results with regard to the relationship between burnout and age therefore seem inconclusive, but since the theory of burnout suggests that burnout might be more of a threat for younger employees, the researchers formulated the second hypothesis to be tested as follows:

- Hypothesis 2: Burnout levels are lower for older age categories (51-60-year-old age group).

\section{Relationship between sense of coherence and burnout: Age as a moderator}

Research indicates overwhelming support for the mitigating impact of sense of coherence on burnout (Johnston et al., 2013), even across various age categories (Haley et al., 2013). However, there seems to be a paucity of research on the relationship between sense of coherence and burnout, taking the influencing effect of age into account.

In investigating age as a moderator, Johnson et al. (2013) found limited support for the moderating effect of age between customer stressors and burnout. They did however find that using emotion-focussed and active coping strategies were more beneficial to prevent burnout for older employees when compared with younger employees using the same coping strategies. They regarded lack of life experience as a possible explanation for these results.

Zaniboni et al. (2013) found that age moderated the relationship between task variety and burnout in that older employees experienced more burnout when task variety increased in comparison to younger employees.

You, Huang, Wang and Bao (2015) found age to be a significant moderator for correlations between exhaustion, depersonalisation and reduced personal accomplishment on the one hand and various personality factors on the other hand.

No research could be found that investigated age as a moderator in the relationship between sense of coherence and burnout.

The purpose of this study is therefore to determine the relationship between age, sense of coherence and burnout and to investigate the moderating effect of age in the relationship between sense of coherence and burnout. The third hypothesis to be tested in this study is as follows:

- Hypothesis 3: Age is a moderator in the relationship between SOC and burnout.

\section{Research design Research approach}

A cross-sectional survey design is used to achieve the objectives of this descriptive study. A cross-sectional design is an economical design that allows one to examine different criterion groups at a single point in time (Spector, 2003).

\section{Research method Participants}

An availability sample $(N=246)$ from an international integrated energy and chemicals company in South Africa

TABLE 1: Characteristics of participants in the sample.

\begin{tabular}{llll}
\hline Item & Category & Percentage & Frequency \\
\hline Gender & Male & 79.3 & 195 \\
& Female & 20.7 & 51 \\
& $18-30$ & 35 & 86 \\
& $31-40$ & 26 & 64 \\
Marital status & $41-50$ & 18.3 & 45 \\
& S1-60 & 18.7 & 46 \\
& Married & 19.5 & 48 \\
& Divorced & 67.9 & 167 \\
& Life partner & 5.7 & 14 \\
& Widowed & 2.4 & 6 \\
\multirow{4}{*}{ Qualification } & Grade 11 and lower & 0.8 & 2 \\
& Grade 11 and lower with trade & 0.8 & 2 \\
& certificate & 1.6 & 4 \\
& Grade 12 & 7.3 & 18 \\
& Grade 12 with trade certificate & 18.7 & 46 \\
& Diploma & 14.6 & 36 \\
& Graduate & 37 & 91 \\
& Honours degree & 15 & 37 \\
\hline
\end{tabular}


participated in the study. The characteristics of the sample are summarised in Table 1. The sample group included mostly male participants $(79.3 \%)$, which is consistent with the predominantly male population in the participating organisations. Participants were between 18 and 60 years of age with most participants falling in the 18-30 year old age category (35\%). They were mostly married (67.9\%) and 37\% of the participants were graduates.

\section{Measuring instruments}

A biographical questionnaire was administered to obtain personal information about the participants such as their age, gender, marital status, qualification and job level.

Orientation to Life Questionnaire (OLQ) (Antonovsky, 1987): The OLQ (Antonovsky, 1987) measures sense of coherence as a total score, which is comprised of three dimensions, namely comprehensibility, manageability and meaningfulness. The questionnaire is a self-completion questionnaire, made up of 29 items that are set up using a seven-point Likert scale ranging from 1 to 7 . In a South African study to determine the reliability, Strümpfer and Wissing (1998) reported Cronbach alphas ranging from 0.74 to 0.94 . The Orientation to Life Questionnaire also shows high test-retest reliability (Cilliers \& Kossuth, 2004). Strümpfer and Wissing (1998) established the validity of the questionnaire in a range of South African studies.

Maslach Burnout Indicator - General Survey (MBI-GS) (Maslach, Jackson \& Leiter, 1996): The MBI-GS measure the incidence of burnout and can be applied to populations beyond the human services occupations (Maslach \& Leiter, 1997). The MBI-GS contains 16 statements divided into three subscales that assess the various aspects of experienced burnout, namely exhaustion, cynicism and lack of professional efficacy. The MBI is a self-administered questionnaire. The respondent is asked to answer statements regarding their job-related feelings on a scale of 0 to 6 , where zero represents never having this feeling about one's job and six represents having this feeling every day. The professional efficacy scale is reverse scored so that a high score on the scale shows reduced efficacy. Maslach et al. (1996) reported high internal consistencies (reliability) with Cronbach alpha coefficients ranging between $0.87-0.89$ for exhaustion; 0.730.74 for cynicism, and $0.76-0.84$ for professional efficacy. Data on test-retest reliabilities after a period of one year were 0.65 for exhaustion, 0.60 for cynicism and 0.67 for professional efficacy. In recent studies, Van Jaarsveld (2004) and Viljoen (2013) found high internal consistency (reliability) in all three subscales, with Cronbach alphas ranging between 0.85 and 0.91. Maslach et al. (1996) found evidence to support the construct validity of the MBI-GS.

\section{Analysis}

The SPSS (version 22.0) program was used for the statistical analysis. Descriptive statistics, alpha coefficients, correlation and ANOVA were calculated to determine the relationship between age, sense of coherence and burnout. Hierarchical multiple regression with the enter method was then used to determine the moderating effects of age on the relationship between sense of coherence and burnout. The data met the standard assumptions with regard to multicollinearity, homoscedasticity and normality of residuals. Predictor, moderator, and outcome variables were z-standardised (Cohen, Cohen, West \& Aiken, 2003). Considering that age is a categorical variable, dummy coding was used to enter it in the hierarchical regression. An interaction term was computed by multiplying the moderator by the independent variable in order to test the moderating effects.

The variables were entered in the following order: Step 1 contained sense of coherence as predictor; Step 2 contained sense of coherence and age as predictors; Step 3 contained sense of coherence, age and the interacting terms of the age categories multiplied by SOC as predictors.

Analyses were conducted for the three separate burnout dimensions. Cohen's (1992) $f^{2}$ effect sizes were calculated to determine the practical significance of the adjusted $R^{2}$ values. Statistical significance was set at 0.05 .

\section{Research procedure}

Ethical clearance was obtained from Unisa to collect the data. The necessary permission was then obtained from the organisation's senior management as well as Human Resources department to administer the instruments in the organisation. An electronic link to a web-based survey document was distributed via email, as well as an information sheet and an informed consent document. The consent form provided a brief introduction to the intent and background of the survey. Employees were reassured of the anonymity of the questionnaires, as well as the voluntary nature of the research. Participants were informed that the research results of the entire group may be shared with the

TABLE 2: Descriptive statistics, alpha coefficients and Pearson correlations of the measuring instruments.

\begin{tabular}{|c|c|c|c|c|c|c|c|c|c|}
\hline Scale & Mean & Standard deviation & $\alpha$ & 1 & 2 & 3 & 4 & 5 & 6 \\
\hline Comprehensibility & 47.48 & 10.51 & 0.81 & - & - & - & - & - & - \\
\hline Manageability & 50.33 & 8.79 & 0.78 & $0.64++$ & - & - & - & - & - \\
\hline Meaningfulness & 43.33 & 7.45 & 0.79 & $0.44+$ & $0.68++$ & - & - & - & - \\
\hline Sense of coherence & 141.19 & 22.77 & 0.90 & $0.85++$ & $0.90++$ & $0.79++$ & - & - & - \\
\hline Exhaustion & 10.60 & 6.89 & 0.91 & $-0.32+$ & $-0.45+$ & $-0.51++$ & $-0.48+$ & - & - \\
\hline Cynicism & 9.56 & 6.65 & 0.79 & $-0.40+$ & $-0.56++$ & $-0.62++$ & $-0.60++$ & $0.56++$ & - \\
\hline Professional efficacy & 29.62 & 5.11 & 0.76 & $0.36+$ & $0.33+$ & $0.45+$ & $0.44+$ & -0.25 & -0.40 \\
\hline
\end{tabular}


management of the organisation, but that no individuals would be identified. The survey duration (approximately 30 minutes) and the survey procedure were discussed and the necessary permission documents were included.

\section{Results}

Firstly, descriptive statistics, alpha coefficients and correlation were conducted to determine the relationship between sense of coherence and burnout. The results are displayed in Table 2 .

From Table 2 it can be seen that all the subscales displayed an acceptable level of reliability ranging from 0.76 (professional efficacy) to 0.91 (exhaustion). According to Pallant (2010), a value of 0.70 is acceptable, with higher values indicating greater reliability. Furthermore, it can be seen that sense of coherence correlated significantly and in the expected direction with the dimensions of burnout (negatively with exhaustion and cynicism and positively with professional efficacy).

Next, an ANOVA was conducted to determine the degree to which sense of coherence and burnout differed with regard to the various age categories. The results are presented in Table 3.

From Table 3 it can be seen that only comprehensibility displayed a statistically significant difference with regard to the age categories. Post-hoc analysis revealed that comprehensibility was significantly lower for the 18- to 30year age group than for the 51-60-year age group. Although reduced professional efficacy and cynicism displayed nonsignificant differences with regard to the age categories $(p=0.05)$, post-hoc analysis revealed that the mean difference

TABLE 3: Analysis of variance between age categories, sense of coherence and burnout.

\begin{tabular}{|c|c|c|c|c|c|c|}
\hline Category & Source of variation & Sum of squares & $d f$ & Mean square & $F$ & Significance \\
\hline \multirow[t]{3}{*}{ Comprehensibility } & Between groups & 1247.759 & 3 & 415.920 & 4.037 & 0.01 \\
\hline & Within groups & 24314.891 & 236 & 103.029 & - & - \\
\hline & Total & 25562.650 & 239 & - & - & - \\
\hline \multirow[t]{3}{*}{ Manageability } & Between groups & 226.156 & 3 & 75.385 & 0.986 & 0.40 \\
\hline & Within groups & 18051.694 & 236 & 76.490 & - & - \\
\hline & Total & 18277.850 & 239 & - & - & - \\
\hline \multirow[t]{3}{*}{ Meaningfulness } & Between groups & 272.790 & 3 & 90.930 & 1.636 & 0.18 \\
\hline & Within groups & 13173.741 & 237 & 55.585 & - & - \\
\hline & Total & 13446.531 & 240 & - & - & - \\
\hline \multirow[t]{3}{*}{ Sense of coherence total } & Between groups & 3271.724 & 3 & 1090.575 & 2.179 & 0.09 \\
\hline & Within groups & 118112.609 & 236 & 500.477 & - & - \\
\hline & Total & 121384.333 & 239 & - & - & - \\
\hline \multirow[t]{3}{*}{ Exhaustion } & Between groups & 235.023 & 3 & 78.341 & 1.671 & 0.17 \\
\hline & Within groups & 11018.475 & 235 & 46.887 & - & - \\
\hline & Total & 11253.498 & 238 & - & - & - \\
\hline \multirow[t]{3}{*}{ Reduced professional efficacy } & Between groups & 210.195 & 3 & 70.065 & 2.724 & 0.05 \\
\hline & Within groups & 6070.738 & 236 & 25.723 & - & - \\
\hline & Total & 6280.933 & 239 & - & - & - \\
\hline \multirow[t]{3}{*}{ Cynicism } & Between groups & 346.949 & 3 & 115.650 & 2.712 & 0.05 \\
\hline & Within groups & 10108.362 & 237 & 42.651 & - & - \\
\hline & Total & 10455.311 & 240 & - & - & - \\
\hline
\end{tabular}

TABLE 4: Moderated multiple regression with exhaustion as the dependent variable.

\begin{tabular}{|c|c|c|c|c|c|c|c|c|c|}
\hline \multirow[t]{2}{*}{ Model } & \multirow[t]{2}{*}{ Variable } & \multicolumn{2}{|c|}{ Unstandardised coefficients } & \multicolumn{3}{|c|}{ Standardised coefficients } & \multirow[t]{2}{*}{$R$} & \multirow[t]{2}{*}{$R^{2}$} & \multirow[t]{2}{*}{ Adjusted $R^{2}$} \\
\hline & & B & SE & Beta & $T$ & $p$ & & & \\
\hline \multirow[t]{2}{*}{1} & Constant & 31.12 & 2.49 & - & 12.51 & 0.00 & 0.48 & 0.23 & 0.22 \\
\hline & Sense of coherence & -0.15 & 0.02 & -0.48 & -8.33 & $0.00 *$ & - & - & - \\
\hline \multirow[t]{5}{*}{2} & Constant & 30.29 & 2.50 & - & 12.11 & 0.00 & 0.50 & 0.25 & 0.23 \\
\hline & Sense of coherence & -0.15 & 0.02 & -0.48 & -8.29 & $0.00 *$ & - & - & - \\
\hline & Age $31-40$ & 2.30 & 1.00 & 0.15 & 2.31 & $0.02 *$ & - & - & - \\
\hline & Age $41-50$ & 0.74 & 1.18 & 0.04 & 0.66 & 0.51 & - & - & - \\
\hline & Age $51-60$ & 0.71 & 1.11 & 0.04 & 0.64 & 0.52 & - & - & - \\
\hline \multirow[t]{7}{*}{3} & Constant & 29.85 & 2.46 & - & 12.16 & 0.00 & 0.54 & 0.29 & 0.27 \\
\hline & Sense of coherence & -0.14 & 0.02 & -0.47 & -8.23 & $0.00 *$ & - & - & - \\
\hline & Age $31-40$ & 2.191 & 0.98 & 0.14 & 2.23 & $0.03^{*}$ & - & - & - \\
\hline & Age $41-50$ & 0.25 & 1.10 & 0.01 & 0.23 & 0.82 & - & - & - \\
\hline & Age $51-60$ & 1.09 & 1.10 & 0.06 & 1.00 & 0.32 & - & - & - \\
\hline & Sense of coherence $x$ age $31-40$ & -0.65 & 0.47 & -0.09 & -1.39 & 0.17 & - & - & - \\
\hline & Sense of coherence $x$ age $51-60$ & -0.89 & 0.43 & -0.14 & -2.08 & $0.04 *$ & - & - & - \\
\hline
\end{tabular}

*, All correlations were significant at the 0.01 level. 
between the 51-60-year age group and the 18-30-year age group was significant at the 0.05 level with the 51-60-yearold age group experiencing less reduced professional efficacy. The 31-40-year-old age group displayed statistically significantly higher levels of cynicism when compared with the 41-50- and 51-60-year-old age groups, respectively.

Next, the main and interaction effects of sense of coherence and age on exhaustion, cynicism and professional efficacy were tested. In order to eliminate the possibility of multicollinearity, only the sense of coherence total score was included in the regression model. The results are displayed in Table 4.

Table 4 shows the regression analysis with exhaustion as dependent variable. From the ANOVA analyses, it follows that the regression model significantly predicted exhaustion at every step (Step 1: $F[1.236]=64.44, p=0.00$; Step 2: $F[4-.233]=18.89, p=0.00$; Step 3: $F[7.230]=13.21, p=0.00)$. The proportion variance explained $\left(R^{2}\right)$ ranged from 0.48 for Step 1 to 0.54 for Step 3 and the adjusted $R^{2}$ were $0.22,0.23$ and 0.27 for Steps 1 to 3 respectively.

It is clear from Table 4 that there were statistically significant main effects for sense of coherence and the age category of 31-40 years old. Only one significant interaction term was found between sense of coherence and the age category 51-60 years old. The interaction term accounted for a statistically significant proportion of variance in exhaustion (change in $\Delta R^{2}=0.04 ; p=0.00$ ) and Cohen's (1992) $f^{2}$ was found to be 0.04 . The moderating effect can therefore be seen as a small practical effect. This significant interaction effect was plotted as indicated in Figure 1.

Figure 1 shows that for a high age group (compared to a lower age group), a low sense of coherence was associated with a higher level of exhaustion. Table 5 presents the possible moderation effect of age on cynicism.

From the ANOVA analyses, it follows that the regression model significantly predicted cynicism at every step (Step 1:
$F[1.238]=133.52, p=0.00$; Step 2: $F[4.235]=35.80, p=0.00$; Step 3: $F[7.232]=20.30, p=0.00)$. The proportion variance explained $\left(R^{2}\right)$ were 0.60 for Step 1, 0.62 for Step 2 and 0.62 for Step 3. The adjusted $R^{2}$ were $0.36,0.37$ and 0.36 for steps 1 to 3 , respectively.

It is clear from Table 5 that there were statistically significant main effects for sense of coherence and the age category of 31 to 40 years old. However, no significant interaction terms were found between sense of coherence and age in predicting cynicism.

Table 6 presents the hierarchical regression analysis with reduced professional efficacy as dependent variable.

From the ANOVA analyses, it follows that the regression model significantly predicted professional efficacy at every step (Step 1: $F[1.238]=133.52, p=0.00$; Step 2: $F[4.235]=35.80$, $p=0.00$; Step 3: $F[7.232]=20.30, p=0.00)$. The proportion variance explained $\left(R^{2}\right)$ were 0.19 for Step 1, 0.20 for Step 2

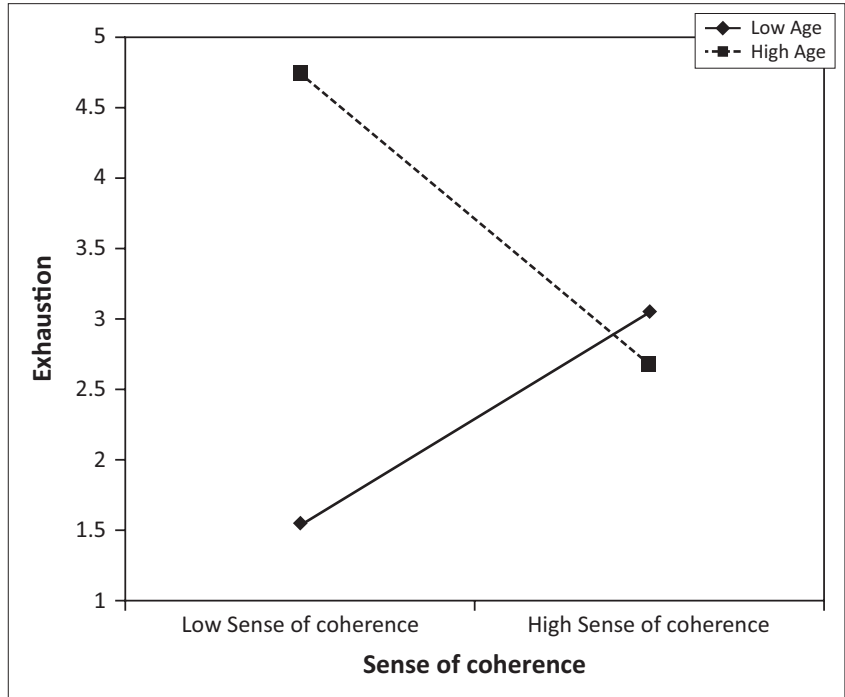

FIGURE 1: Interaction between sense of coherence and age with exhaustion as dependent variable.

TABLE 5: Moderated multiple regression with cynicism as the dependent variable.

\begin{tabular}{|c|c|c|c|c|c|c|c|c|c|}
\hline \multirow[t]{2}{*}{ Model } & \multirow[t]{2}{*}{ Variable } & \multicolumn{2}{|c|}{ Unstandardised coefficients } & \multicolumn{3}{|c|}{ Standardised coefficients } & \multirow[t]{2}{*}{$R$} & \multirow[t]{2}{*}{$R^{2}$} & \multirow[t]{2}{*}{ Adjusted $R^{2}$} \\
\hline & & B & SE & Beta & $t$ & $p$ & & & \\
\hline \multirow[t]{2}{*}{1} & Constant & 34.34 & 2.17 & - & 15.85 & 0.00 & 0.60 & 0.36 & 0.36 \\
\hline & Sense of coherence & -0.18 & 0.02 & -0.60 & -11.56 & $0.00 *$ & - & - & - \\
\hline \multirow[t]{5}{*}{2} & Constant & 33.40 & 2.18 & - & 15.34 & 0.00 & 0.62 & 0.38 & 0.37 \\
\hline & Sense of coherence & -0.17 & 0.02 & -0.60 & -11.41 & $0.00^{*}$ & - & - & - \\
\hline & Age $31-40$ & 2.23 & 0.87 & 0.15 & 2.58 & $0.01 *$ & - & - & - \\
\hline & Age $41-50$ & 0.40 & 0.98 & 0.02 & 0.41 & 0.68 & - & - & - \\
\hline & Age $51-60$ & 0.38 & 0.97 & 0.02 & 0.39 & 0.70 & - & - & - \\
\hline \multirow[t]{7}{*}{3} & Constant & 33.40 & 2.20 & - & 15.21 & 0.00 & 0.62 & 0.38 & 0.36 \\
\hline & Sense of coherence & -0.17 & 0.02 & -0.60 & -11.28 & $0.00 *$ & - & - & - \\
\hline & Age $31-40$ & 2.17 & 0.88 & 0.15 & 2.48 & $0.01 *$ & - & - & - \\
\hline & Age $41-50$ & 0.37 & 0.99 & 0.02 & 0.37 & 0.71 & - & - & - \\
\hline & Age $51-60$ & 0.33 & 0.99 & 0.02 & 0.33 & 0.74 & - & - & - \\
\hline & Sense of coherence $x$ age $31-40$ & -0.27 & 0.42 & -0.04 & -0.65 & 0.52 & - & - & - \\
\hline & Sense of coherence $x$ age $51-60$ & -0.05 & 0.39 & -0.01 & -0.14 & 0.89 & - & - & - \\
\hline
\end{tabular}

*, All correlations were significant at the 0.01 level. 
TABLE 6: Moderated multiple regression with professional efficacy as the dependent variable.

\begin{tabular}{|c|c|c|c|c|c|c|c|c|c|}
\hline \multirow[t]{2}{*}{ Model } & \multirow[t]{2}{*}{ Variable } & \multicolumn{2}{|c|}{ Unstandardised coefficients } & \multicolumn{3}{|c|}{ Standardised coefficients } & \multirow[t]{2}{*}{$\boldsymbol{R}$} & \multirow[t]{2}{*}{$R^{2}$} & \multirow[t]{2}{*}{ Adjusted $R$} \\
\hline & & B & SE & Beta & $t$ & $p$ & & & \\
\hline \multirow[t]{2}{*}{1} & Constant & 15.67 & 1.90 & - & 8.27 & 0.00 & 0.43 & 0.19 & 0.19 \\
\hline & Sense of coherence & 0.10 & 0.01 & 0.43 & 7.41 & $0.00 *$ & - & - & - \\
\hline \multirow[t]{4}{*}{2} & Constant & 15.75 & 1.92 & - & 8.21 & 0.00 & 0.45 & 0.20 & 0.19 \\
\hline & Sense of coherence & 0.09 & 0.01 & 0.42 & 7.01 & $0.00 *$ & - & - & - \\
\hline & Age $31-40$ & 0.21 & 0.77 & 0.02 & 0.27 & 0.79 & - & - & - \\
\hline & Age $51-60$ & 1.50 & 0.85 & 0.12 & 1.75 & 0.08 & - & - & - \\
\hline \multirow[t]{7}{*}{3} & Constant & 15.48 & 1.91 & - & 8.13 & 0.00 & 0.48 & 0.23 & 0.20 \\
\hline & Sense of coherence & 0.10 & 0.01 & 0.42 & 7.19 & 0.00 & - & - & - \\
\hline & Age $31-40$ & 0.33 & 0.76 & 0.03 & 0.44 & 0.66 & - & - & - \\
\hline & Age $41-50$ & 0.93 & 0.86 & 0.07 & 1.08 & 0.28 & - & - & - \\
\hline & Age $51-60$ & 1.81 & 0.86 & 0.14 & 2.12 & $0.04 *$ & - & - & - \\
\hline & Sense of coherence $x$ age $31-40$ & 0.59 & 0.36 & 0.11 & 1.65 & 0.10 & - & - & - \\
\hline & Sense of coherence $x$ age $51-60$ & -0.44 & 0.33 & -0.09 & -1.32 & 0.19 & - & - & - \\
\hline
\end{tabular}

*, All correlations were significant at the 0.01 level.

and 0.23 for Step 3. The adjusted $R^{2}$ were $0.19,0.19$ and 0.20 for steps 1-3, respectively.

It is clear from Table 4 that there were statistically significant main effects for sense of coherence and the age category of 51-60 years old at Step 3. However, no significant interaction terms were found between sense of coherence and age in predicting professional efficacy.

\section{Discussion}

The purpose of this study was to determine the relationship between age, sense of coherence and burnout and to determine if age moderated the relationship between sense of coherence and burnout.

Hypothesis 1 states that older age categories would have higher SOC levels. The current study's findings partially support Hypothesis 1. Results revealed that employees in the 51-60-year-old age category experienced higher levels of comprehensibility than employees in the 18-30 year old age category. This seems to be in line with the findings of Feldt $e t$ al. (2011), Haley et al. (2013), and Mattisson et al. (2014) who also found that SOC increases with age. Comprehensibility refers to employees' perception that their environment is structured and ordered and that this makes it possible to anticipate and find structure in future events (Antonovsky, 1987). Constant experiences form the basis for the comprehensibility dimension and this result in individuals being able to make sense of stressful life experiences on a cognitive level. In making sense of stressors, individuals learn through their own life experiences to cope more effectively with stressors. The results of this study seems to confirm that the mastering of work and life experiences over a period of time contribute to the development of SOC, or comprehensibility specifically in the context of this study. The results also alludes to the fact that younger employees new to the working environment may not be able to make cognitive sense of stressors in their working environment in the same way as older employees who already have a number of years of work experience (Haley et al., 2013).
Hypothesis 2 states that older age categories would have lower levels of burnout. Looking only at the results of the ANOVA, it seems that the findings of this study did not support Hypothesis 2 and appeared to be in alignment with the findings of Bezuidenhout and Cilliers (2011) who also did not find any relationship between age and burnout. However, upon inspection of the rest of the results, it seems that although no statistically significant differences could be found between the various age categories and exhaustion, cynicism and reduced professional efficacy, some age categories could be used as predictors of these dimensions in addition to SOC. The 31-40-year-old age category significantly predicted exhaustion and cynicism, whilst the 51-60-yearold age category significantly predicted reduced professional efficacy. This seems to be more in line with the findings of previous studies (Ben-Porat \& Itzhaky, 2014; Brewer \& Shapard, 2004; Haley et al., 2013; Jackson \& Rothmann, 2005; Johnson et al., 2013; Rothmann \& Barkhuizen, 2008) that found significant differences between age groups and their burnout levels. It does however need to be stated that the age categories just seem to add a percentage of explained variance each time in addition to the percentage of variance that is already explained by SOC. Nevertheless, it seem that, apart from an employees' SOC level, being in the 31-40-yearold age category or the 51-60 year old age category, could also be indicative of the degree of burnout that an employee might be experiencing.

Hypothesis 3 states that age moderates the relationship between SOC and burnout. The findings of the current study partially support Hypothesis 3 as only one indirect effect was found. The 51- to 60-year-old age category moderated the relationship between SOC and exhaustion. The interaction showed an enhancing effect. It seems that having a high level of SOC were more beneficial to prevent exhaustion for employees older than 51 years of age when compared to younger employees with the same level of SOC. These results seem to be in alignment with that of Johnson et al. (2013) who also found limited support for the moderating effect of 
age between coping strategies and burnout. However, the moderating effect was small in practical terms.

\section{Implications and recommendations for the organisation}

A practical contribution of this study is an increased understanding of the implications of an age-diverse group of employees when developing and implementing wellbeing interventions in an organisation. The results of this study seems to confirm that employees that are 51 years and older experience higher levels of well-being and lower levels of burnout than their younger colleagues (Haley et al., 2013). If they do experience levels of exhaustion, it seems that increasing their SOC might be especially helpful in combating this dimension of burnout. These older employees may therefore act as a source of support and as mentors to younger employees. In order to address the comprehensibility of younger employees, organisations may revisit their induction programs. The latter could be specifically focussed on presenting the organisation in a clear, coherent and consistent manner, pointing out resources that are available to their employees and showing the worth of contributing to the organisation's overall performance in a meaningful way. Employees in the 31-40 year old age category could be specifically targeted for interventions that are aimed at reducing burnout, like revisiting the specific job demands and job resources that this age category has to deal with that could predict their levels of burnout (Haley et al., 2013), as well as addressing potential work-family conflict (Culpin et al., 2015) that they might experience.

\section{Limitations of the study and recommendations for further research}

The first limitation of the study is that it made use of a crosssectional design when the data were collected. A longitudinal study could indicate causal relationships regarding age, burnout and SOC. The nonprobability sample size is also quite small and this limits the generalisability of the results. Larger, random samples in other industries could be included in future studies to see if the difference in SOC and burnout could be generalised to other populations as well. Participants were not asked to indicate their job tenure in the study. Because of the relationship between age and work experience, this could have been an important variable to consider in this study and future research could investigate this aspect in more detail.

\section{Conclusion}

In conclusion, it seems that employees that are 51 years and older experienced higher levels of comprehensibility, lower levels of reduced professional efficacy and lower levels of exhaustion, especially when coupled with a high SOC. On the other hand, it seems that employees between 31 and 40 years old might be more susceptible to exhaustion and cynicism.

\section{Acknowledgements Competing interests}

The authors declare that they have no financial or personal relationships which may have inappropriately influenced them in writing this article.

\section{Authors' contributions}

S.v.d.W. (University of South Africa) conceptualised the research problem of the current study, conducted the statistical analysis and literature review and wrote up the research article. C.H. (SASOL) and A.V. (SASOL) collected the data.

\section{References}

Abdool Karrim Ismail, H., Coetzee, N., Du Toit, P., Rudolph, E.C., \& Joubert, Y.T. (2013) Towards gaining a competitive advantage: The relationship between burnout, job satisfaction, social support and mindfulness. Journal of Contemporary Management, 10, 448-464.

Antonovsky, A. (1987). Unraveling the mystery of health. How people manage stress and stay well. San Francisco: Jossey-Bass.

Asiwe, D.N., Jorgensen, L.I., \& Hill, C. (2014). The development and investigation of the psychometric properties of a burnout scale within a South African agricultural research institution. SA Journal of Industrial Psychology/SA Tydskrif vir Bedryfsielkunde, 4O(1), Art. \#1194, 14 pages. http://dx.doi.org/10.4102/sajip. v40i1.1194

Barnard, A. (2013). The role of socio-demographic variables and their interaction effect on sense of coherence. SA Journal of Industrial Psychology/SA Tydskrif vir Bedryfsielkunde, 39(1), Art. \#1073, 9 pages. hhttp://dx.doi.org/10.4102/\%20sajip. v39i1.1073

Ben-Porat, A., \& Itzhaky, H. (2014). Burnout among trauma social workers: The contribution of personal and environmental resources. Journal of Social Work, 15(6), 606-620. http://dx.doi.org/10.1177/1468017314552158

Bezuidenhout, A., \& Cilliers, F. (2011). Age, burnout, work engagement and sense of coherence in female academics at two South African universities. South African Journal of Labour Relations, 35(1), 61-80.

Boehm, S.A., \& Kunze, F. (2015). Age diversity and age climate in the workplace. In P.M. Bal, D.T.A.M. Kooij, \& D.M. Rousseau (Eds.), Aging workers and the employeeemployer relationship (pp. 33-55). Cham: Springer International Publishing.

Brewer, E.W., \& Shapard, L. (2004). Employee burnout: A meta-analysis of the relationship between age or years of experience. Human Resource Development Review, 3, 102-123. http://dx.doi.org/10.1177/1534484304263335

Cilliers, F., \& Kossuth, S.P. (2004). The reliability and factor structure of three measures of salutogenic functioning. South African Journal of Labour Relations, 28(2), 59-

Cohen, J. (1992). A power primer. Psychological Bulletin, 112(1), 155-159.

Cohen, J., Cohen, P., West, S., \& Aiken, L.S. (2003). Applied multiple regression/ correlation analysis for the behavioral sciences. (3rd edn.). MahwahJ: Lawrence Erlbaum Associates.

Culpin, V., Millar, C., \& Peters, K. (2015). Multi-generational frames of reference: Managerial challenges of four social generations in the organisation. Journal of Managerial Psychology, 30(1), n.p. http://0-dx.doi.org.oasis.unisa.ac.za/10.1108/ JMP-08-2014-0231

Dychtwald, K., Erickson, T. J., \& Morison, R. (2013). Workforce Crisis: How to beat the coming shortage of skills and talent. Boston, MA: Harvard Business School Publishing.

Eriksson, M., \& Lindström, B. (2005). Validity of Antonovsky's sense of coherence scale: A systematic review. Journal of Epidemiology and Community Health, 59(6), 460-466. PMID: 15911640, http://dx.doi.org/10.1136/jech.2003.018085

Feldt, T., Leskinen, E., Koskenvuo, M., Suominen, S., Vahtera, J., \& Kivimäki, M. (2011) Development of sense of coherence in adulthood: A person-centred approach The population-based HeSSup cohort study. Quality of Life Research, 20, 69-79. PMID: 20686925, http://dx.doi.org/10.1007/s11136-010-9720-7

Hansen, J.C., \& Leuty, M.E. (2012). Work values across generations. Journal of Career Assessment, 20(1), 34-52. http://dx.doi.org/10.1177/1069072711417163

Haley, L., Mostert, K., \& Els, C. (2013). Burnout and work engagement for different age groups: Examining group-level differences and predictors. Journal of Psychology
in Africa, 23(2), 283-295. http://dx.doi.org/10.1080/14330237.2013.10820625

Hochwälder, J., \& Forsell, Y. (2011). Is sense of coherence lowered by negative life events? Journal of Happiness Studies, 12, 475-492. http://dx.doi.org/10.1007/ s10902-010-9211-0

Iweins, C., Desmette, D., Yzerbyt, V., \& Stinglhamber, F. (2013). Ageism at work: The impact of intergenerational contact and organizational multi-age perspective. European Journal of Work and Organizational Psychology, 22(3), 331-346. http:// dx.doi.org/10.1080/1359432X.2012.748656

Jackson, L.T.R., \& Rothmann, S. (2005). An adapted model of burnout for educators. South African Journal of Education, 225(2), 100-108. 
Johnson, S.J., Holdsworth, L., Hoel, H., \& Zapf, D. (2013). Customer stressors in service organizations: The impact of age on stress management and burnout. European organizations: The impact of age on stress management and burnout. European
Journal of Work and Organizational Psychology, 22(3), 318-330. http://dx.doi.org Journal of Work and Organizational

Johnston, C.S., De Bruin, G.P., Györkös, C., Geldenhuys, M., Massoudi, K., \& Rossier, J. (2013). Sense of coherence and job characteristics in predicting burnout in a South African sample. SA Journal of Industrial Psychology/SA Tydskrif vir Bedryfsielkunde, 39(1), Art. \#1096, 9 pages. http://dx.doi.org/10.4102/ sajip. v39i1.1096

Louw, D.A., George, E., \& Esterhuyse, K. (2011). Burnout amongst urban secondary school teachers in Namibia. South African Journal of Industrial Psychology, 37(1) Art. \#1008, 7 pages, http://dx.doi.org/10.4102/sajip.v37i1.1008

Maslach, C., Jackson, S.E., \& Leiter, M.P. (1996). Maslach burnout inventory manual. (3rd edn.). Palo Alto: Consulting Psychologists Press.

Maslach, C., \& Leiter, M.P. (1997). The truth about burnout. CA: Wiley.

Maslach, C., Schaufeli, W.B., \& Leiter, M.P. (2001). Job burnout. Annual Review of Psychology, 52(1), 397-422. PMID: 11148311, http://dx.doi.org/10.1146/ annurev.psych.52.1.397

Mattisson, C., Horstmann, V., \& Bogren, M. (2014). Relationship of SOC with sociodemographic variables, mental disorders and mortality. Scandinavian sociodemographic variables, mental disorders and mortality. Scandinavian
Journal of Public Health, 42, 434-445. PMID: 24662308, http://dx.doi. Journal of Public Health, 42,
org/10.1177/1403494814527188

Mauno, S., Ruokolainen, M., \& Kinnunen, U. (2013). Does aging make employees more resilient to job stress? Age as a moderator in the job stressor-wellbeing relationship in three Finnish occupational samples. Aging \& Mental Health 17(4), 411-422. PMID: 23215801, http://dx.doi.org/10.1080/13607863.2012.7 47077

Mousavy, S., \& Nimehchisalem, V. (2014). Contribution of gender, marital status, and age to English language teacher's burnout. Advances in Language and Literary Studies, 5(6), 39-47.

Pallant, J. (2010). SPSS survival manual. (4th edn.). NY: McGraw-Hill.

Rothmann, S., \& Barkhuizen, N. (2008). Burnout of academic staff in South African higher education institutions. South African Journal of Higher Education, 22(2) 439-456. http://dx.doi.org/10.4314/sajhe.v22i2.25796

Rothmann, S., \& Malan, M.M. (2006). Occupational stress of engineers in South Africa. Southern African Business Review, 10(2), 1-16.
Schaufeli, W.B., \& Enzmann, D. (1998). The burnout companion to study and practice: A critical analysis. London: Taylor \& Francis.

Smit, J. (2007). The influence of stressors and coping strategies on burnout and compassion fatigue among health care professionals. Unpublished doctoral dissertation, University of the Free State, Bloemfontein, South Africa.

Strümpfer, D.J.W., \& Wissing, M.P. (1998). Review of South African data on the sense of coherence scale as a measure of fortigenesis and salutogenesis, 8-11 September 1998. Cape Town: 4th Annual Congress of the Psychological Society of South Africa.

Spector, P.E. (2003). Industrial and organizational psychology: Research and design. (3rd edn.). Hoboken: John Wiley \& Sons, Inc.

Storm, K., \& Rothmann, S. (2003). A psychometric analysis of the Maslach Burnout Inventory-General survey in the South African Police service. South African Journal of Psychology, 33(4), 219-226. http://dx.doi.org/10.1177/008124630303300404

Van Jaarsveld, J. (2004). The relationship between, burnout, coping and sense of coherence amongst engineers and scientists. Unpublished master's dissertation, University of South Africa, Pretoria.

Van Schalkwyk, L., \& Rothmann, S. (2008). Validation of the orientation to life questionnaire (OLQ) in a chemical factory. South African Journal for Industrial Psychology, 34(2), 31-39. http://dx.doi.org/10.4102/sajip.v34i2.725

Virtanen, P., \& Koivisto, A.M. (2001). Wellbeing of professionals at entry into the labour market: a follow-up survey of medicine and architecture students. Journal of Epidemiology and Community Health, 55, 831-835. http://dx.doi.org/10.1136/ jech.55.11.831

Viljoen, A. (2013). Burnout, coping and sense of coherence in an engineering organisation. Unpublished master's dissertation, Unisa, Pretoria, South Africa.

Wainwright, N.W.J., Surtees, S., Welch, A.A., Luben, R.N., Khaw, K.T., \& Bingham, S.A. (2008). Sense of coherence, lifestyle choices and mortality. Journal of Epidemiology and Community Health, 62, 829-831. PMID: 18701735, http:// dx.doi.org/10.1136/ jech.2007.066464

You, X., Huang, J., Wang, Y., \& Bao, X. (2015). Relationships between individual-level factors and burnout: A meta-analysis of Chinese participants. Personality and Individual Differences, 74, 139-145. http://dx.doi.org/10.1016/j.paid.2014.09.048

Zaniboni, S., Truxillo, D.M., \& Fraccaroli, F. (2013). Differential effects of task variety and skill variety on burnout and turnover intentions for older and younger workers. European Journal of Work and Organizational Psychology, 22(3), 306317. http://dx.doi.org/10.1080/1359432X.2013.782288 